\title{
The Cancer Stem Cell Conundrum in Multiple Myeloma
}

\section{Robert G. Hawley ${ }^{1,2 *}$}

${ }^{1}$ Department of Anatomy and Regenerative Biology, George Washington University, Washington, DC, USA

${ }^{2}$ Sino-US Joint Laboratory of Translational Medicine, Jining Medical University Affiliated Hospital, Jining Medical University, Jining, Shandong, China

The cancer stem cell (CSC) hypothesis in its original form postulates that a small subpopulation of cancer cells is responsible for propagation of the tumor [1]. By comparison to normal stem cells, CSCs are predicted to be drug-resistant due to increased expression of proteins such as anti-alkylating enzymes like aldehyde dehydrogenase (ALDH) that neutralize the therapeutic agents [2] or members of the ATP-binding cassette $(\mathrm{ABC})$ family of transporters that efflux them out of the cells [3].

Multiple myeloma (MM) is an incurable malignancy of B-lymphoid cells characterized by the accumulation of differentiated plasma cells in the bone marrow. MM is responsible for over 30,000 deaths each year in the United States and the European Union. While patients initially respond to therapy, they eventually relapse because the MM cells acquire drug resistance [4].

Demonstration of a low percentage of clonogenic cells in the bulk tumor mass prompted a search for the CSC in MM [5]. But contradictory results have been obtained regarding the phenotype of the proposed tumor-propagating cells; moreover, the relationship between drugresistant MM cells at relapse and putative MM CSCs remains a matter of much debate [6-18]. A subpopulation of clonogenic MM cells has been described having a memory $\mathrm{B}$ cell-like phenotype $\left(\mathrm{CD} 19^{+} \mathrm{CD} 20^{+} \mathrm{CD} 27^{+}\right)$ [6]. Although $\mathrm{CD} 19^{+} \mathrm{CD} 20^{+} \mathrm{CD} 27^{+} \mathrm{MM}$ cells lacked the characteristic plasma cell antigen $\mathrm{CD} 138$, they were capable of differentiating into $\mathrm{CD}_{138^{+}}$plasma cells [7]. These studies suggested that $\mathrm{MM}$ is organized in a hierarchical manner and that $\mathrm{CD} 19^{+} \mathrm{CD} 20^{+} \mathrm{CD} 27^{+} \mathrm{MM}$ cells might represent a putative MM CSC [19] . However, other work indicates that such cells might represent a premalignant intermediate [20]. Their biological significance has also been questioned based on their rarity. For example, one study investigating the clonal hierarchy in light chain MM was unable to confirm the presence of tumor-specific immunoglobulin sequences in the memory B cell compartment [10]. A number of other recent reports have also failed to obtain evidence in support of this supposition $[13,14,16]$. These latter results are consistent with the prevailing assumption that neoplastic transformation in MM occurs at a post-memory B cell stage when somatic hypermutation of immunoglobulin genes has ceased [21,22].

Various strategies have been employed to prospectively isolate and study CSC-like tumor-propagating cells. One common approach is based on the expression of cell surface markers that are characteristic of the stem cell phenotype of the corresponding normal tissue. An example of this approach involves expression of the CD34 cell surface marker of immature hematopoietic cells (see [23] for review). It is of interest in this regard that a subpopulation of $\mathrm{CD} 138^{+} \mathrm{MM}$ cells has been reported to express CD34 [8].

Another approach capitalizes on the functional properties of stem cells. As noted above, stem cells are highly resistant to damage by toxic agents through a combination of mechanisms [2,3,24,25]. Some of these attributes can be exploited by flow cytometry-based procedures to enrich for stem-like cells $[23,26]$. Efflux of the vital dye Hoechst 33342 by the ABCG2 and/or ABCB1 transporters identifies a subset of cells in a variety of normal and malignant tissues-termed "side population" (SP) cells-which displays stem cell-like properties [27,28]. Interestingly, variable results have also been obtained concerning the SP phenotype in human MM cell lines and patient samples. Using this assay, one group identified a clonogenic CD138 $13{ }^{\text {neg }} \mathrm{MM}$ subpopulation that was resistant to the anti-MM agent lenalidomide [7] whereas another group subsequently described the characterization of clonogenic SP cells in MM that primarily expressed CD138 and were sensitive to lenalidomide [9]. Likewise, ALDH has been shown to be a marker of CSC-like cells in a wide range of tumors, including the B-lymphoid malignancies Hodgkin lymphoma and mantle cell lymphoma $[29,30]$. Although it has been reported that certain MM cell cultures as well as patient samples contained subpopulations of $\mathrm{ALDH}^{+}$ cells with a CSC-like phenotype $[7,18]$, the generality of this finding has been questioned [17].

How can these discrepant observations be reconciled? On the one hand, it is important to appreciate that MM is characterized by significant molecular heterogeneity, comprising at least seven disease subtypes [31]. A potential scenario that could also help to integrate the incongruent observations would be if malignant transformation of $\mathrm{CD} 138^{+}$post-memory B cells results in the acquisition of a CSClike phenotype [32], e.g., by a "dedifferentiation" mechanism that is akin to the cellular reprogramming that occurs during the generation of induced pluripotent stem cells $[22,33,34]$. Indeed, activation of the MYC proto-oncogene, one of four transcription factors used in the initial reprogramming experiments [35], is a recurring event in MM pathogenesis [36].

Thus, the putative MM CSC would not be expected to be a single genetic entity; rather, genetically-distinct subtype-associated CSCs are predicted. Furthermore, it would not be surprising if MM CSCs exhibit phenotypic variability during tumor progression as a result of epigenetic changes and genomic instability [37]. Considered in this light, it will be a challenging task but well worth the effort to delineate all of the MM CSC subpopulations. The clinical implications are profound in that subtype-specific concerted therapies targeting the bulk as well as the various CSC fractions of the tumor will undoubtedly be necessary if an effective cure is to be found for this devastating collection of diseases.

\section{Acknowledgement}

This work was supported by a Grant from the Dr. Cyrus and Myrtle Katzen Cancer Research Center at The George Washington University.

*Corresponding author: Robert G. Hawley, Department of Anatomy and Regenerative Biology, George Washington University, Washington, DC, USA E-Mail: rghawley@gwu.edu

Received October 19, 2012; Accepted October 20, 2012; Published October 22, 2012

Citation: Hawley RG (2012) The Cancer Stem Cell Conundrum in Multiple Myeloma. J Stem Cell Res Ther 2:e110. doi:10.4172/2157-7633.1000e110

Copyright: ( 2012 Hawley RG. This is an open-access article distributed under the terms of the Creative Commons Attribution License, which permits unrestricted use, distribution, and reproduction in any medium, provided the original author and source are credited. 


\section{References}

1. Dick JE (2008) Stem cell concepts renew cancer research. Blood 112: 47934807.

2. Alison MR, Guppy NJ, Lim SM, Nicholson LJ (2010) Finding cancer stem cells: are aldehyde dehydrogenases fit for purpose? J Pathol 222: 335-344.

3. Moitra K, Lou H, Dean M (2011) Multidrug efflux pumps and cancer stem cells: insights into multidrug resistance and therapeutic development. Clin Pharmacol Ther 89: 491-502.

4. Mahindra A, Laubach J, Raje N, Munshi N, Richardson PG, et al. (2012) Latest advances and current challenges in the treatment of multiple myeloma. Nat Rev Clin Oncol 9: 135-143.

5. Hamburger A, Salmon SE (1977) Primary bioassay of human myeloma stem cells. J Clin Invest 60: 846-854

6. Matsui W, Huff CA, Wang Q, Malehorn MT, Barber J, et al. (2004) Characterization of clonogenic multiple myeloma cells. Blood 103: 2332-2336.

7. Matsui W, Wang Q, Barber JP, Brennan S, Smith BD, et al. (2008) Clonogenic multiple myeloma progenitors, stem cell properties, and drug resistance. Cancer Res 68: 190-197.

8. Kuranda K, Berthon C, Dupont C, Wolowiec D, Leleu X, et al. (2010) A subpopulation of malignant CD34+CD138+B7-H1+ plasma cells is present in multiple myeloma patients. Exp Hematol 38: 124-131.

9. Jakubikova J, Adamia S, Kost-Alimova M, Klippel S, Cervi D, et al. (2011) Lenalidomide targets clonogenic side population in multiple myeloma: pathophysiologic and clinical implications. Blood 117: 4409-4419.

10. Pfeifer S, Perez-Andres M, Ludwig H, Sahota SS, Zojer N, et al. (2011) Evaluating the clonal hierarchy in light-chain multiple myeloma. Leukemia 25: 1213-1216.

11. Van Valckenborgh E, Matsui W, Agarwal P, Lub S, Dehui X, et al. (2012) Tumor-initiating capacity of CD138- and CD138+ tumor cells in the 5T33 multiple myeloma model. Leukemia 26: 1436-1439.

12. Chiron D, Surget S, Maïga S, Bataille R, Moreau P, et al. (2012) The periphera CD138+ population but not the CD138- population contains myeloma clonogenic cells in plasma cell leukaemia patients. $\mathrm{Br} \mathrm{J}$ Haematol 156: 679683.

13. Trepel M, Martens V, Doll C, Rahlff J, Gösch B, et al. (2012) Phenotypic detection of clonotypic B cells in multiple myeloma by specific immunoglobulin ligands reveals their rarity in multiple myeloma. PLoS One 7: e31998.

14. Hosen N, Matsuoka Y, Kishida S, Nakata J, Mizutani Y, et al. (2012) CD138negative clonogenic cells are plasma cells but not $B$ cells in some multiple myeloma patients. Leukemia 26: 2135-2141.

15. Christensen $\mathrm{JH}$, Jensen PV, Kristensen IB, Abildgaard N, Lodahl M, et al. (2012) Characterization of potential CD138 negative myeloma "stem cells". Haematologica 97: e18-e20.

16. Kim D, Park CY, Medeiros BC, Weissman IL (2012) CD19-CD45low/-CD38high/ CD138+ plasma cells enrich for human tumorigenic myeloma cells. Leukemia doi: 10.1038/leu.2012.140 [Epub ahead of print].

17. Paíno T, Ocio EM, Paiva B, San-Segundo L, Garayoa M, et al. (2012) CD20 positive cells are undetectable in the majority of multiple myeloma cell lines and are not associated with a cancer stem cell phenotype. Haematologica 97 1110-1114.

18. Boucher K (2012) Stemness of B cell progenitors in multiple myeloma bone marrow. Clin Cancer Res: doi: 10.1158/1078-0432.CCR-12-0531 [Epub ahead of print].

19. Szczepek AJ, Bergsagel PL, Axelsson L, Brown CB, Belch AR, et al. (1997) CD34+ cells in the blood of patients with multiple myeloma express CD19 and IgH mRNA and have patient-specific IgH VDJ gene rearrangements. Blood 89 : 1824-1833.

20. Rasmussen T, Haaber J, Dahl IM, Knudsen LM, Kerndrup GB, et al. (2010) Identification of translocation products but not K-RAS mutations in memory $\mathrm{B}$ cells from patients with multiple myeloma. Haematologica 95: 1730-1737.

21. Bakkus MH, Heirman C, Van Riet I, Van Camp B, Thielemans K, et al. (1992) Evidence that multiple myeloma Ig heavy chain VDJ genes contain somatic mutations but show no intraclonal variation. Blood 80: 2326-2335.
22. Takishita M, Kosaka M, Goto T (1994) Cellular origin and extent of clonal involvement in multiple myeloma: genetic and phenotypic studies. $\mathrm{Br} J$ Haematol 87: 735-742.

23. Hawley RG, Ramezani A, Hawley TS (2006) Hematopoietic stem cells. Methods Enzymol 419: 149-179.

24. Diehn M, Cho RW, Lobo NA, Kalisky T, Dorie MJ, et al. (2009) Association of reactive oxygen species levels and radioresistance in cancer stem cells. Nature 458: 780-783.

25. Riz I and Hawley RG (2009) Genomic stability in stem cells. In: Rajasekha VK, Vemuri MC, editors. Regulatory Networks in Stem Cells. New York, NY: Humana Press/Springer: 67-74.

26. Eaker SS, Hawley TS, Ramezani A, Hawley RG (2004) Detection and enrichment of hematopoietic stem cells by side population phenotype. Methods Mol. Biol 263: 161-180

27. Goodell MA, Brose K, Paradis G, Conner AS, Mulligan RC (1996) Isolation and functional properties of murine hematopoietic stem cells that are replicating in vivo. J Exp Med 183: 1797-1806

28. Ramos CA, Venezia TA, Camargo FA, Goodell MA (2003) Techniques for the study of adult stem cells: be fruitful and multiply. BioTechniques 34: 572-578, 580-584, 586-591.

29. Jones RJ, Gocke CD, Kasamon YL, Miller CB, Perkins B, et al. (2009) Circulating clonotypic B cells in classic Hodgkin lymphoma. Blood 113: 5920 5926.

30. Brennan SK, Meade B, Wang Q, Merchant AA, Kowalski J, et al. (2010) Mantle cell lymphoma activation enhances bortezomib sensitivity. Blood 116: 41854191.

31. Zhan F, Huang Y, Colla S, Stewart JP, Hanamura I, et al. (2006) The molecular classification of multiple myeloma. Blood 108: 2020-2028.

32. Luckey CJ, Bhattacharya D, Goldrath AW, Weissman IL, Benoist C, et al (2006) Memory T and memory B cells share a transcriptional program of selfrenewal with long-term hematopoietic stem cells. Proc Natl Acad Sci USA 103 3304-3309.

33. Yaccoby S (2005) The phenotypic plasticity of myeloma plasma cells as expressed by dedifferentiation into an immature, resilient, and apoptosisresistant phenotype. Clin Cancer Res 11: 7599-7606.

34. Vierbuchen T, Wernig M (2012) Molecular roadblocks for cellular reprogramming. Mol Cell 47: 827-838

35. Takahashi K, Tanabe K, Ohnuki M, Narita M, Ichisaka T, et al. (2007) Induction of pluripotent stem cells from adult human fibroblasts by defined factors. Cell 131: 861-872.

36. Chng WJ, Huang GF, Chung TH, Ng SB, Gonzalez-Paz N, et al. (2011) Clinica and biological implications of MYC activation: a common difference between MGUS and newly diagnosed multiple myeloma. Leukemia 25: 1026-1035.

37. Visvader JE, Lindeman GJ (2012) Cancer stem cells: current status and evolving complexities. Cell Stem Cell 10: 717-728. 